\title{
Experiences of selected West Virginia agriculture teachers who have established aquaculture units in their schools and have taught aquaculture classes for two years or more
}

\author{
Paul A. Lovett \\ West Virginia University
}

Follow this and additional works at: https://researchrepository.wvu.edu/etd

\footnotetext{
Recommended Citation

Lovett, Paul A., "Experiences of selected West Virginia agriculture teachers who have established aquaculture units in their schools and have taught aquaculture classes for two years or more" (1999). Graduate Theses, Dissertations, and Problem Reports. 983.

https://researchrepository.wvu.edu/etd/983

This Thesis is protected by copyright and/or related rights. It has been brought to you by the The Research Repository @ WVU with permission from the rights-holder(s). You are free to use this Thesis in any way that is permitted by the copyright and related rights legislation that applies to your use. For other uses you must obtain permission from the rights-holder(s) directly, unless additional rights are indicated by a Creative Commons license in the record and/ or on the work itself. This Thesis has been accepted for inclusion in WVU Graduate Theses, Dissertations, and Problem Reports collection by an authorized administrator of The Research Repository @ WVU. For more information, please contact researchrepository@mail.wvu.edu.
} 


\title{
EXPERIENCES OF SELECTED WEST VIRGINIA AGRICULTURE TEACHERS WHO HAVE ESTABLISHED AQUACULTURE UNITS IN THEIR SCHOOLS AND HAVE TAUGHT AQUACULTURE CLASSES FOR TWO YEARS OR MORE
}

\author{
Paul A. Lovett
}

Thesis submitted to

The College of Agriculture, Forestry and Consumer Science

at West Virginia University

in partial fulfillment of the requirements

for the degree of

Master of Science

in

Agricultural Education

Layle D. Lawrence, Ph.D., Chair

Stacy A. Gartin, Ph.D.

Gary J. Wingenbach, Ph.D.

Department of Agriculture and Environmental Science

Morgantown, West Virginia

1999

Keywords: Aquaculture, Agriculture, Teacher, Education 


\section{ABSTRACT \\ EXPERIENCES OF SELECTED WEST VIRGINIA AGRICULTURE TEACHERS WHO HAVE ESTABLISHED AQUACULTURE UNITS IN THEIR SCHOOLS AND HAVE TAUGHT AQUACULTURE CLASSES FOR TWO YEARS OR MORE}

\section{Paul A. Lovett}

This study was designed to ascertain and record the experiences of West Virginia agriculture teachers who have established aquaculture units in their schools and have taught aquaculture for two or more years. This study will provide suggestions to those who may yet integrate aquaculture into their curriculum.

A "Focused Interview" was used to gather qualitative data from eight-experienced aquaculture teachers. The respondents answered eight questions that were asked and recorded by the secretary in agricultural and environmental education at WVU to eliminate bias and improve the validity of this study.

The results of this study found that agricultural teachers used aquaculture to enhance and increase interest in their agricultural program. The optimum size of an aquaculture facility is teacher dependent and is used to reinforce science skills and concepts and is being promoted as a viable Supervised Agriculture Experience Program. Agriculture teachers would start an aquaculture education program again. 


\section{Acknowledgments}

With grateful appreciation I would like to give thanks to my advisor and committee chair Dr. Layle Lawrence who has been a true mentor and example to me. Dr. Lawrence over the years has always been there for me and has given his time and effort to help me mature as a teacher and as a person. I am thankful for the many hours that Dr. Lawrence has spent in my behalf in helping me with my thesis; words alone cannot express how grateful I am to him.

I would like to thank Dr. Stacy Gartin and Dr. Gary Wingenbach for their Northeastern Region Survey on the benefits of aquaculture in the agriculture programs. The work that was done helped tremendously and was a basis for my topic. I am thankful for the time that each of you has spent in helping review my thesis.

A special thanks to Alice Compton, secretary in the agricultural and environmental education department, for calling and interviewing the participants of the survey.

I would like to also thank my wife, Kristi, for understanding the time that is needed away from home in working with the agricultural youth in Monroe County. 
Table of Contents

Page

Acknowledgments

ii

$\begin{array}{lll}\text { Chapter } 1 \quad \text { Introduction } & 1\end{array}$

Chapter 2 Review of Literature 4

Chapter 3 Design and Methodology 8

$\begin{array}{lll}\text { Chapter } 4 & \text { Findings } & 11\end{array}$

Chapter 5 Summary, Conclusions and Recommendations 22

$\begin{array}{ll}\text { Bibliography } & 28\end{array}$

$\begin{array}{ll}\text { Appendices } & 30\end{array}$

A. Letter to Participants 32

B. Interview Schedule 34

$\begin{array}{ll}\text { Abstract } & 36\end{array}$

$\begin{array}{ll}\text { Vita } & 37\end{array}$

$\begin{array}{ll}\text { Signature Page } & 38\end{array}$ 


\section{Chapter 1}

Introduction

Aquaculture, the science of producing aquatic plants and animals for human use is a component of and type of agriculture. It is similar to, but different from traditional farming.

Traditional farming occurs on land, requires space and water and can grow and produce a variety of plant and animal products. Aquaculture uses water as a media, maximizes space and can produce variety of plant and animal products.

Aquaculture is thought of in the U.S. as a relatively new way to produce food and fiber, however many civilizations developed and used some type of aquaculture to produce food for their people. In searching through history one can find that the Chinese as early as 3500 B.C. cultivated carp, the Egyptians focused on tilapia, and the Romans grew mullet and trout. In North America, the utilization of natural marine food base stocks such as mussels, clams, and oysters dates back to the pilgrims (Miller, 1980).

Today, within the U.S., species such as tilapia, perch, carp, trout, and catfish are grown commercially in ponds and in flow-through and recirculation systems. The inclusion of aquaculture courses in the 1980's in the states of Massachusetts, Hawaii, New Jersey, and Connecticut have helped make aquaculture a viable educational option In West Virginia 27 out of 78 schools are infusing aquaculture experiential opportunities in their secondary agriculture education programs (Michael, 1998). The potential for increased braiding of curriculums, experiential learning, increased job opportunities, and potential economic development within communities has enhanced both the awareness and teaching of aquaculture at the secondary level. 
While an aquaculture program is not essential in every school and, indeed, may not be appropriate in many schools, there is little doubt that a number of schools will initiate programs in the future. It may be useful at this time to ascertain information and advice from teachers who have established and operated aquaculture programs for some time with respect to their experiences which might provide guidance for those who will establish programs in the future.

\section{$\underline{\text { Statement of Problem }}$}

In West Virginia, a large amount of resources have been funneled into secondary agricultural education programs to infuse aquaculture into the curriculum. The effect on curriculum content, extended employment, cross-curriculum teaching and experiential learning opportunities are perceived as beneficial factors. Experiential learning is being hailed as the only true method of providing life-long scientific and mathematical skills for secondary students. More aquaculture programs will be initiated in the future. What can be learned from the "pioneers" in aquaculture education in West Virginia? What suggestions might they offer to those who may yet develop programs in aquaculture? This study was designed to ascertain and record the experiences of West Virginia agriculture teachers who have established aquaculture units in their schools and have taught aquaculture classes for two or more years. A compilation of such experiences may provide guidance and may prove to be beneficial for those who will initiate aquaculture programs in the future as well as for school administrators, state staff and teacher educators in the State. 


\section{Purpose of the Study}

The primary objective of the study was to ascertain and record experiences of secondary teachers in West Virginia with respect to establishment and operation of aquaculture programs in their schools. Specific research questions are:

1. Why did teachers decide to offer aquaculture in their schools?

2. What did teachers remove from their curricula in order to offer aquaculture?

3. What have been the greatest payoffs from offering aquaculture classes?

4. What have been the biggest drawbacks of offering aquaculture classes?

5. What would be the optimum size of an aquaculture facility in a school system for educational purposes?

6. What should be the focus for teaching aquaculture in the high school agriculture program (e.g., to teach science concepts, to promote production, job skills and employment, etc.)?

7. To what extent is aquaculture as a Supervised Agriculture Experience Program being promoted?

8. What would teachers do differently if they were to begin anew? 


\section{Chapter 2}

\section{Review of Literature}

A review of related literature revealed limited resources dealing with the problems that hinder the establishment of an aquaculture program. However, some research was reported concerning programs, number of students taking an aquaculture course, characterization of agriculture teachers, and perceived barriers to establishing and maintaining an aquaculture program. Major concepts acquired from the literature were evaluated and applied to this study.

El-Ghamrini (1996) as reported by Gartin \& Wingenbach (1997) stated that aquaculture education in the U.S. mainly started around the 1990s and has been integrated into the agricultural education curriculum through workshops, conferences, field trips, and demonstrations. The purpose of his study was to determine factors that led to the adoption of aquaculture education, perceived barriers to starting and maintaining an aquaculture program, technologies used, and the effectiveness of aquaculture publications produced by the National Council for Agricultural Education. State supervisors in 12 states (Wisconsin, Illinois, Iowa, Kansas, Minnesota, Nebraska, North Dakota, Ohio, Missouri, Indiana, South Dakota, and, Michigan) identified agricultural education instructors who taught aquaculture and 141 teachers responded to the study.

It was found that agriculture teachers who adopted aquaculture taught in small schools, taught in single teacher departments, liked new curricula, liked science, and found aquaculture interesting to teach. The aquaculture curriculum motivated students, added prestige to the agriculture program, added hands-on science experiences, and 
related well to the environment. Potential barriers to starting and maintaining an aquaculture program were identified. Barriers that rated the highest were care of fish on weekends and holidays, facility limitations, low teacher knowledge, high equipment costs, and possibility of failure.

Conroy \& Peasley's (1997) report, as reported by Gartin and Wingenbach (1997), centers around a follow-up survey to one conducted by Dr. Thomas Garrison, Vocational Director of South Putnam Area High School (Greencastle, Indiana) in 1995. Dr. Garrison's survey analysis was from 33 states and Guam and assessed the number of secondary programs offering aquaculture education, number of students enrolled, workshops attended, and level of support.

The follow-up telephone survey completed by Conroy \& Peasley (1997) defined an aquaculture unit as "one period per day for at least one semester per year." The survey found that 463 programs offered aquaculture to 11,674 students with Alabama reporting the greatest number of aquaculture programs. Aquaculture was also being infused into 702 agriculture programs providing 20,635 students with experiential learning in mathematics and science that compliment theory.

The survey conducted by Gartin \& Wingenbach (1997) dealt with eleven Northeastern States (Pennsylvania, New York, West Virginia, Connecticut, Maryland, Delaware, New Jersey, Vermont, New Hampshire, Maine, and Rhode Island) of which over one-half (38 out of 70) of all usable research instruments were returned by teachers in Pennsylvania, New York, and West Virginia. The survey instrument used was modified from El-Ghamrini’s (1996) “Assessing the Educational Benefits of Teaching 
Aquaculture in Secondary Agriculture Education Programs" and was guided by fifteen research objectives, within eight sections.

Within the study there were three sections that provided base-line data of perceived educational benefits and program constraints in establishing and maintaining an aquaculture program. Survey results showed the average age of the respondents was $41.13,71 \%$ of whom were males; $67 \%$ had a master's degree and the average length of teaching experience was 16 years. The average aquaculture teaching experience was 4.4 years and participants became aware of aquaculture by attending conferences, workshops, and course work.

The section "Factors affecting the decision to teach aquaculture" was comprised of 17 factors generated by the researcher: Participants rated the importance of those factors on a four-point Thurstone-type scale. The top five responses were similar to ElGhamrini's (1996) results:

1. relates to natural resource/conservation.

2. motivates students.

3. fits into curriculum.

4. interesting to teachers.

5. provides a means for more science within the Agriculture Education curriculum.

In the second section " Possible barriers to implementing an aquaculture education program," respondents rated the importance of 18 questions on a four-point Thurstone-type scale. The results indicate that limited facilities to house the aquaculture program, the need to take care of the fish on weekends or holidays, the high cost associated with start-up, low teacher knowledge and limited teaching material were 
among the most important of the perceived barriers. It is important to note that limited job opportunities was also among the top barriers identified. Within this section female agriculture teachers and younger male teachers rated limited teacher material higher than their male counterparts who had advanced degrees.

Also of importance to this study were teacher attitudes related to aquaculture. Respondents indicated their level of agreement with 13 statements on a five-point Likert scale. The statements concerned attitudes towards aquaculture and the aquaculture industry. No significant differences were found when teacher's attitudes were compared by state, age, or gender (Gartin \& Wingenbach 1997).

In summary, the literature review shows that aquaculture in the secondary schools is relatively new. The average aquaculture teaching experience was 4.4 years as reported by Gartin \& Wingenbach (1997). El-Ghamrini (1996) and Gartin \& Wingenbach (1997) have expressed the need for more research concerning aquaculture in the secondary schools. The purpose of this study, therefore, is to obtain information from established aquaculture teachers concerning their experiences in establishing and maintaining an aquaculture facility. 


\section{Chapter 3}

\section{Design and Methodology}

This study was designed to ascertain and record experiences of secondary agriculture teachers in West Virginia with respect to establishment and operation of aquaculture programs in their schools. Such information may be useful to teachers who may consider initiating aquaculture programs in the future as well as to state staff and teacher educators.

In order to acquire data for this study, a qualitative method of research utilizing a focused interview technique was used.

A focused interview is a way of gathering qualitative data by asking individuals questions about their behavior. A focused interview is much more flexible and open in form than the survey interview... The respondents are free to answer in their own words, and can answer either briefly or at length... The responses are recorded by taking notes, either during the interview of immediately afterward, or with an audiotape. (Ary, Jacobs \& Razavieh, 1996, p. 487)

Focused interviews are also used to ascertain perceptions of experiences. (Ary, Jacobs \& Razavieh, 1996)

The primary objective of the study was to ascertain and record experiences of secondary agriculture teachers in West Virginia with respect to establishment and operation of aquaculture programs in their schools. Specific research questions were:

1. Why did teachers decide to offer aquaculture in their schools?

2. What did teachers remove from their curricula in order to offer aquaculture?

3. What have been the greatest payoffs from offering aquaculture classes? 
4. What have been the biggest drawbacks of offering aquaculture classes?

5. What would be the optimum size of an aquaculture facility in a school system for educational purposes?

6. What should be the focus for teaching aquaculture in the high school agriculture program (e.g., to teach science concepts, to promote production, job skills and employment, etc.)?

7. To what extent is aquaculture as a Supervised Agriculture Experience Program being promoted?

8. What would teachers do differently if they were to begin anew?

\section{$\underline{\text { Population }}$}

The population for this study $(\mathrm{N}=8)$ consisted of high school agriculture teachers in West Virginia during the 1998-99 school year who have initiated and operated aquaculture classes for two or more years. The population was identified by consultation with teacher educators at West Virginia University.

$\underline{\text { Method }}$

A qualitative method of research using the focused interview technique was used to survey a selected group of secondary agricultural education teachers in West Virginia. Prior to the interview, letters were mailed to the population informing them of the purposes of the study and listing the questions that they would be asked in the interview. This process alerted the teachers to the study, and gave them time to reflect on the questions to be answered. One week later, Alice Compton, secretary in agricultural and environmental education at West Virginia University, who had been trained in the interview process and given an interview schedule to follow, telephoned each participant. 
Permission was asked to record responses and, upon approval, the participant was asked to respond to each of the questions. Responses were recorded on tape for later transcription by the researcher. Removing the researcher from the interview process was an effort to improve validity of the study and remove any bias that might result from the researcher conducting the interviews himself.

$\underline{\text { Data Analysis }}$

Data obtained through telephone surveys were transcribed by the researcher and are presented in Chapter 4. Since this was a focused interview study, statistical analysis was not utilized in data analysis. 


\section{Chapter 4}

\section{Findings}

This study was designed to ascertain and record the experiences of West Virginia agriculture teachers who have established aquaculture units in their schools and have taught aquaculture for two of more years. A compilation as such experiences may provide guidance and may prove to be beneficial for those teachers who will initiate aquaculture programs in the future as well as for school administrators, state staff, and teacher educators in the state.

Data for the study were acquired through a qualitative method of research using the focused interview technique. Telephone interviews were conducted with the eight agriculture teachers in West Virginia who had initiated aquaculture units in their schools and had taught aquaculture classes for two or more years. To avoid bias, interviews were conducted by the secretary of the agriculture and environmental education discipline at West Virginia University who had been trained in interview techniques and who followed an interview schedule during the interview process. Data obtained through telephone surveys were transcribed by the researcher. Specific research questions posed during the interviews included:

1. Why did you decide to offer aquaculture in their schools?

2. What did you remove from your curriculum, or how did you modify your curriculum, in order to offer aquaculture classes?

3. What has been the greatest payoff from offering aquaculture classes?

4. What have been the biggest drawbacks of offering aquaculture classes? 
5. What would be the optimum size of an aquaculture unit in a school system for educational purposes?

6. What should be the focus for teaching aquaculture in the high school agriculture program (for example, to teach science concepts? to promote aquaculture production? to teach employment skills?)

7. To what extent is aquaculture as a Supervised Agriculture Experience Program being promoted?

8. With regard to the aquaculture program, what would you do differently if you had it to do over?

This chapter presents the information obtained through the telephone interviews regarding each of the eight research questions.

Why Teachers Decided to Offer Aquaculture in Their Schools

It was considered important to determine what factors motivated teachers to initiate aquaculture programs in their schools. The following responses to the question, "Why did you decide to offer aquaculture in your school?" were received:

- To try to broaden the student's horizons and interests; to let them experience new things.

- To increase interest in the program.

- ... provide a hands on experience for my students, that would combine a lot of scientific methods and theories that they could use. We've been running beef cattle at school. Once the school consolidated we lost all of our land so we had to sell all of our cattle. That's where the fish came in, we were able to have a 
species that you could have a large number and do a variety of things with in a controlled space.

- Because of the changing needs of students and their interests.

- To basically enhance the agricultural program. To add a little flavor as far as the science applications to it and the water testing and so on. It makes it a little easier to work with a project in a laboratory situation rather than trying to go out and use ponds. It is a more controlled environment. It's easier to teach record keeping skills and business skills to students.

- Just to expand the opportunities in agriculture.

- We wanted to give our students a wider choice of electives they could take.

- It was here when I first moved here. ... where kids could take up information and ideas for their own use on farms, or possibly make money. Something different to attract the kids.

\section{$\underline{\text { How Teachers Modified Their Curriculums in Order to Offer Aquaculture Classes }}$}

In order to include aquaculture in the school's agricultural education curriculum, other topics either had to be reduced or eliminated. Teachers were asked the question, "What did you remove from your curriculum, or how did you modify your curriculum, in order to offer aquaculture classes?" Their responses are as follows:

- I don't know, because that was done before I was here.

- We really didn't modify anything other than getting another teacher, which allowed us to do that.

- Basically nothing other than agricultural mechanics, but I incorporated it into the regular agriculture class. 
- Basically, what I do now as far as record keeping and those types of things, I use the aquaculture system. I really haven't eliminated anything. ...

- We consolidated a mechanics offering and allowed another teacher who is better able to teach mechanics, which freed me up to teach aquaculture.

- ... We really didn't lose anything; we gained more agriculture courses with aquaculture being offered.

- We didn't have to remove anything. We offered a special topics course where the students are working on their own in a self directed type of class. There are worksheets in the filing cabinet and they follow the directions for the activities each day.

- It wasn't really modified at all. We have a new facility where we are teaching and I was able to design the course however I wanted. That's just one component of several different activities.

\section{$\underline{\text { Payoff From Offering Aquaculture Classes }}$}

Aquaculture is considered a program that is multi-disciplined and technical in nature. New programs in agriculture can provide various benefits to the entire school community. Teacher's responses to the question, "What has been the greatest payoff from offering aquaculture classes?" are as follows:

- Probably the increased enrollment.

- We're getting more academically oriented students into our program.

- A lot of long hours. No, let me be more serious. I think the opportunity to pull in a different segment of students. 
- Probably the greatest thing is student's ability to watch an animal go from start to finish, students being able to get all the scientific aspects of it and use those in part of the curriculum....

- The diversity of students we have been able to attract.

- Just seeing the kids take ownership. We had some babies hatch out this year and the kids really got excited about that. They liked watching them grow.... You could tell they hadn't had the opportunity to have something that was really theirs and it made a difference to them.

- Recognition from the Board of Education, from the public, and from the school staff, science teachers particularly, because of the success we have had at the science fairs. Student achievement, seeing students to the National Lab or Science Fair, and International Science and Engineering Fair.

- I would think the educational experiences the kids have had through water testing and learning how important it is to daily maintain and take care of the aquaculture system.

\section{$\underline{\text { Drawbacks of Offering Aquaculture Classes }}$}

Working with animals in an agriculture curriculum posse many challenges that affect the teacher and students. Teacher's responses to the question, "What have been the biggest drawbacks of offering aquaculture classes?" are as follows:

- The odor in my classroom. We have problems occasionally with the odor and the filters not working properly.... 
- Probably the time restraint, having to feed them on a daily basis through the summer if we decide to keep them that way. Time is probably the biggest thing.

- The time you have to spend to maintain the facility.

- Long hours

- The biggest drawback I see in dealing with the aquaculture system is the amount of time it takes to get the system going...

- The time it takes to run the aquaculture lab.

- Time. The time you put into getting the curriculum started, the time you put into building the program. That's the biggest drawback, it's the amount of time you spend in the aquaculture building....

- All the extra time that it takes to operate the lab and to take care of problems that come up.

\section{$\underline{\text { Optimum Size of an Aquaculture Unit For Education }}$}

In a laboratory setting there is a theoretically optimum size that provides the greatest educational benefit to students and provides equal opportunities for all. Teachers were asked the question, "What do you think would be the optimum size of an aquaculture unit in a school system designed for educational purposes?" Their responses are as follows:

- I think if I had one 440-gallon tank that seems sufficient.

- It depends on what the teacher wants to do with it.

- I would say probably two to four tanks, 300 to 400 gallons per tank would be adequate to allow enough room to grow and do a variety of things that way. 
- I think it needs to be a size to accommodate research type projects rather than production oriented.

- Personally I don't think any person needs any more than 100 or 200 hundred gallon tanks and they can probably teach as good a program aquacultural wise as you could teach with a larger system such as we have.

- I think that there should be a couple different tanks.... It's based upon the teacher, their time and their ability. One exact system for everybody isn't the answer.

- I think educationally, ideally would be to have some aquariums, probably a three or four tank system where you can run them through different stages ... of about 1600 gallon system, ... along with some aquariums so you can raise some babies and maybe do some tropical or maybe experiments done or student generated projects.

- Five to ten tanks of about 150 gallons, I like the smaller tanks rather than the larger tanks.

Focus for Teaching Aquaculture in a High School Setting

West Virginia agriculture curriculum is designed to provide students with job entry or college entry skills in an agriculture field. The role of aquaculture in the total program is considered important to determine how it is taught. Teachers were asked to respond to the question, "In your opinion, what should be the focus for teaching aquaculture in a high school agriculture program (for example, to teach science concepts, to promote aquaculture production, to teach employment skills)?" The following responses were given: 
- ... to teach science skills. To learn about the possibilities to have employment, maybe more of a part-time than a full time, kind of a side occupation.

- I think everything. I think it should touch on all aspects of what you mentioned, and more.

- I think probably to teach students all that you can about the field of aquaculture and at the same time try to promote the field of aquaculture.

- I think you need to do it more from the scientific aspect, research. The handson is great, but if you get into production you have so much repeat throughout the year. I'm not sure that is what we should be doing at the high school level.

- To integrate the science into the program. Using the dissolved oxygen, learning about ammonia, those types of things. Being able to teach water quality and how important water quality is to the livelihood of not only animals, but ourselves.

- The curriculum needs to be driven by the student needs. The class should not be driven by the lab itself.

- ... I like the attention for what it does in combining science and agriculture. It really opens the kids up to how important it is to know their science... Depending on the teacher it can be blended in however you like.... What we have decided to do is to teach the husbandry part because we have a lot of kids that don't have the opportunity to be on a farm. So it gives them that farm, that hands-on experience that seems to make them a better student. 
- To promote aquaculture, to teach science concepts, to teach employment skills.

\section{$\underline{\text { Aquaculture as an Supervised Agricultural Experience Program }}$}

Supervised Agricultural Experience Programs provide students a foundation for an agriculture career by transferring knowledge learned within a class into a production or placement work experience program. It was important to determine if students were actually starting experience programs in aquaculture. The following responses to the question, "To what extent is aquaculture as a Supervised Agricultural Experience Program being promoted outside of school?" were received:

- Very little, at least in our area.

- I have one student who is raising 10,000 trout and another student whose family runs a "Fish for Fun" enterprise.

- I have three students, I think that is only going to expand. That depends on the area you are in and the acceptance you get from the community, but I think the potential is there.

- I have students that are raising fish in local ponds for themselves. I do have some students that are interested in doing some type of fee fishing at their homes in ponds. The only thing you have to watch about that is insurance. Some students are having a hard time finding insurance that will cover them with that type of endeavor. But I do have students that are working with the aquaculture trying to use those toward supervised experience programs.

- We're promoting it, for instance, we passed out trout and then our students will be taking those trout and designing individual mini-systems for at home. 
- We're promoting it a little bit. We haven't had too much success. I think everybody is looking to see what is happening.... We're promoting it as a way of supplementing an income, of supplementing a food source for home, a diversification...

- I think the same emphasis as all other Supervised Agricultural Experience possibilities.

- We have very few students involved in it as a Supervised Agricultural Experience Program. Some of them do raise fish, but it is just for their own pleasure, not as a moneymaking thing.

\section{What Would You Do Differently If You Had It To Do Over}

Hindsight is often said to be $20 / 20$. Looking back and learning from mistakes is how we learn. Teachers who have operated aquaculture programs for over two years have a perspective that needs to be considered. Their responses to the question, "With regards to the aquaculture program, what would you do differently if you had it to do over" are as follows:

- Actually, probably have two tanks. One tank has been working well, but it doesn't allow you to experiment. With two tanks you can do some different types of management (feeding and so forth).

- I'm not sure that I would do it.

- I'd put it outside and make sure there are drains next to each of the tanks.

- I'm not sure. It wouldn't be the size we currently have. I would keep it smaller and more confined to research rather than production. 
- The biggest thing I would is that the program would be smaller. I do not think you need a full-fledged system like the one at Monroe, Mineral, and the one at Cameron. I think they are way too large. I think they are taking too much time out of the curriculum because if something happens you have to attend to that deal. Just this morning something happened with the aquaculture system, so I'm running around like I'm crazy in order to get ready to teach class.

- That's difficult to answer. Not that much really, just try to identify additional people to assist.

- I'd learn a little more before I started into it. Sometimes we have a tendency to think we know more than what we do. I would take a little more time to study and research it and get a little more help. I lost a bunch of fish over the last couple of years just mainly due to inexperience. ...

- It has to do with the physical plan itself. I would modify the design that we have on a recirculating system and particularly with emphasis on a back up system for power failures. Also, try to make allowances for increased flow rate of the system. 


\section{Chapter 5}

\section{Summary, Conclusions, and Recommendations}

\section{$\underline{\text { Summary }}$}

The object of this study was to determine experiences of agricultural education teachers in West Virginia who had initiated aquaculture programs in their schools and had taught aquaculture classes for two or more years. A descriptive method of research using the focused interview technique was utilized in this study. Information was obtained from eight agriculture teachers involved through telephone interviews using an interview schedule. Since this was a focused study, statistical analysis was not used in data analysis.

Findings of the study are summarized as follows:

1. Agriculture teachers offered aquaculture in their schools primarily to enhance the agriculture program as reported by five of the eight teachers. The other three teachers used aquaculture as a way to increase interest in their agriculture program.

2. In order to offer aquaculture classes five of the eight interviewed teachers did not reduce of eliminate courses from their curriculum to accommodate an aquaculture course. Two of the eight consolidated an agriculture mechanics course to teach aquaculture. 
3. The greatest payoff from including aquaculture in the curriculum mentioned by four of the eight teachers was the diversity of students who enrolled in their class because of the aquaculture program. Also considered important was the opportunity to watch and care for the fish from start to finish by three teachers, and one teacher mentioned the opportunity for recognition of their students.

4. The biggest drawback in offering aquaculture classes within the agriculture curriculum, as identified by seven of the eight teachers interviewed, is the amount of time the aquaculture facility requires from the teacher. Also mentioned was the odor that is produced when raising fish.

5. In looking at the optimum size one should have for an educational aquaculture facility three teachers interviewed recommended a system consisting of two to four tanks with a capacity of 300 to 400 gallons each. Two teachers thought smaller tanks of 100 to 200 gallons each were better than a large tank system. Two teachers thought that the aquaculture system should be dependent upon the teacher and his of her abilities. One teacher thought that the emphasis should be on research rather than production.

6. The focus for teaching aquaculture that five out of eight teachers mentioned was to teach science skills and concepts. One teacher thought that the curriculum should be geared towards the student's needs. One teacher surveyed thought that it was important to also promote the field of aquaculture. 
7. Aquaculture as a Supervised Experience Program is being promoted by six of the eight teachers interviewed. One teacher had students raising fish for their own pleasure and one teacher promoted aquaculture very little in his or her area.

8. In looking back at their aquaculture program the changes that would be made are: two teachers would downsize, one would increase in size, and one would move their system outside. Other suggestions include learning more before getting started, modifying by adding a back up system, finding more people to help with the program, and one teacher is not sure if he or she would do it over again.

\section{$\underline{\text { Conclusions }}$}

From the analysis of the responses received from the population of eight West Virginia agriculture teachers who initiated aquaculture units in their schools and who have taught aquaculture classes for two years or more, the following conclusions were drawn:

1. Aquaculture is offered in West Virginia schools to enhance the agricultural program and bring a diversity of students into the program.

2. The aquaculture program fits into the agriculture curriculum with very few modifications. The main program aquaculture has a tendency to affect is agricultural mechanics.

3. Aquaculture education's biggest drawback is the amount of time required by the teacher in maintaining the facility. 
4. Aquaculture classes attract academically oriented students, increase enrollment and provide recognition for students.

5. The optimum size of an aquaculture facility is dependent upon the teacher and the educational purpose.

6. Aquaculture is offered in West Virginia as a means of teaching science concepts.

7. Aquaculture is being promoted as a viable Supervised Agriculture Experience Program.

8. Agriculture education teachers in West Virginia who have aquaculture programs would start an aquaculture education program if they had it to do over again.

\section{$\underline{\text { Recommendations }}$}

This study was designed to investigate experiences of West Virginia agriculture teachers who have initiated aquaculture programs in their schools and who have taught aquaculture classes for two or more years. Analysis of responses of the eight participants reveals several suggestions that would be of value to teachers who are contemplating initiation of aquaculture programs in their schools, of which the most significant are condensed and presented in the form of recommendations. Suggestions for additional research that might be beneficial are also presented.

1. The decision of starting an aquaculture program hinges on the question; "Do you have the time to devote to the project"? Time is the biggest drawback to consider in the start up of an aquaculture program. Time is required each day to maintain the facility. Water has to be tested, feed needs to be weighed and 
fed, fish need to be graded, systems require back-flushing and addition of make up water. A potential solution to the problem is to give the students the ownership of the program by using it as a Supervised Experience Program, a co-op opportunity, or as a school-to-work student mentoring site.

2. The second question to consider is the housing of the aquaculture program. Do I have to give up one program to add another? Thought needs to go into the location because of the humidity, odor, need for floor drains, and space for the tanks. The teachers surveyed felt that a 2 to 4 tank system would work well in providing research projects for the students, and is manageable from a teacher perspective. Space requirements needed would be a 10 -foot by 20 -foot area.

3. Aquaculture education should emphasize the reinforcement of science and mathematics skills. The hands-on-experiences in chemistry, biology, genetics, nutrition, record keeping, and computer usage help attract a diversity of students into the agriculture program. Aquaculture curriculum, when shared with other teachers during the year creates collaborative real life experiences that reinforce skills taught within each curriculum

4. Aquaculture can be a viable Supervised Experience Program. More emphasis needs to be put into teaching a total aquaculture program than just production of a single species. If that is done more students will start businesses in water gardens and aquatic plants, tropical fish production, bait fish production, and small scale sustainable farm systems. 
5. Before starting an aquaculture program the teacher should take time to study the different programs throughout the state, learn all that he or she can about systems and different aquatic species, and consider what the focus of the aquaculture program is to be. One needs to study the local community and county and then decide how aquaculture can fit into the total agriculture program.

Additional research is needed in the following areas:

1. How much time do teacher's spend in an aquaculture program? Is it only perceived or actually a time consuming program?

2. What is the cost involved with set up and maintenance of an aquaculture program?

3. To what extent does teaching aquaculture reinforce science and math concepts?

4. What are good viable Supervised Agricultural Experience Programs that aquaculture students can enter into? 


\section{Bibliography}

Ary, D., Jacobs, L. \& Razavieh, A. (1996). Introduction to research in education. ( $5^{\text {th }}$ ed.). Ft. Worth: Harcourt Brace College Publishers.

Bevers, S.J., \& Ruppel, F.J. (1989, September). A new era in the classroom: the economics of agriculture. The Agricultural Education Magazine, $\underline{62}$, 8-9.

Committee on Agricultural Education, Board on Agriculture, National Research Council (1988). Understanding Agriculture: New Direction for Education. Washington, DC. National Academy Press.

Conroy, C. \& Peasley, D. (1997). National aquaculture curriculum phase I evaluation report. Submitted to the National Council for Agricultural Education/USDA.

Cox, D.E., McCormick, F.G., \& Miller, G.M. (1989, May). Agriculture education model. The Agriculture Education Magazine, $\underline{61}, 9-12$.

El-Ghamrini, S. A. (1996) Adoption of aquaculture education by high school agriculture teachers in the central region of the United States. Unpublished doctoral dissertation, Iowa State University.

Gartin, S. A. \& Wingenbach, G. J. (1997) Assessing the Educational Benefits of Teaching Aquaculture in Secondary Agricultural Education Programs: A Northeastern Region Survey. Submitted to the Northeastern Region Aquaculture Center.

Goldhor, H. (1974). The use of late respondents to estimate the nature on nonrespondents. Washington, DC: U.S. Office of Education. (ERIC Document ED 083 309).

Harvey, D. (1998). Aquaculture Outlook, March, USDA.

High Schools begin aquaculture courses. (1981). Aquaculture Magazine, 8(1), 53.

Kahler, A.K. (1988). The purpose and delivery of instruction about agriculture. The Journal of the American Association of Teacher Educators in Agriculture, 29, 3-11.

Law, D.A. (1990, March). Implementing agricultural literacy programs. The Agriculture Education Magazine, $\underline{62}, 5-6$.

Lawrence, L.D. (1991, June). Secondary Agricultural Strategy (An Alternative to the Traditional Approach). Agricultural Education Department, West Virginia University.

Leising, J.G. (1990, February). Agriculture literacy: Challenge of the nineties. The Agriculture Education Magazine, 62. 
Michael, D. (1998, Nov.-Dec.). West Virginia AG. ED. News and Views. West Virginia University, pg. 6.

Miller, B. A. (1980). Historical review of U.S. musses culture and harvest. IN:R.A. Lutz(Ed.), Mussel culture and harvest: A North American perspective. New York: Elseiver Scientific Publishing Company.

Moore, G.E. \& Borne, C. (1986, Fall). The secondary vocational agriculture curriculum from 1890-1980. The Journal of the American Association of Teacher Educators in Agriculture, 27, 8-19.

Moss, J.W. (1989, May). Moving day for teacher education. The Agriculture Education Magazine, 3.

Norris, R.J. \& Briers, G.E. (1989, Spring). Perceptions of secondary agricultural science teachers toward proposed changes in agricultural curricula in Texas. Journal of Agricultural Education $30,32-43$.

Parker, R. (1995). Aquaculture Science, Delmar Publishers

Rosenfeld, S.A. (1987, December). Human resource development in rural America: Rays of sunshine through the clouds. U.S.D.A. Annual Agricultural Outlook Conference, 9. 
Appendices 
Appendix A

Letter to Participants 
April x, 1999

Mr./Ms. Xxxxxx Xxxxxx

Any High School

Town , WV Zip

Dear Mr./Ms. Xxxxxxxxx,

We are conducting a Masters thesis study designed to ascertain experiences of selected West Virginia agriculture teachers who have established aquaculture units in their schools and have taught aquaculture classes for two years or more. You are one of those teachers selected for participation. We hope to provide information that might be useful for teachers who may consider establishing aquaculture units in their schools in the future.

In the next week or so, the secretary in agricultural and environmental education at West Virginia University will telephone you and request brief answers to eight questions. They are:

1. Why did you decide to offer aquaculture in your school?

2. What did you remove from your curriculum, or how did you modify your curriculum, in order to offer aquaculture classes?

3. What has been the greatest payoff from offering aquaculture classes?

4. What have been the biggest drawbacks of offering aquaculture classes?

5. What would be the optimum size of an aquaculture unit in a school system for educational purposes?

6. What should be the focus for teaching aquaculture in the high school agriculture program (for example, to teach science concepts? to promote aquaculture production? to teach employment skills?)

7. To what extent is aquaculture as a Supervised Agriculture Experience Program being promoted?

9. With regard to the aquaculture program, what would you do differently if you had it to do over?

Your participation in this study, of course, is voluntary. And if there are questions you prefer not to answer, please disregard them. However, to be of most value, your responses are very important. Rest assured that your responses will remain confidential, and neither you nor your school will be identified in data presentation.

Since the interview will be conducted by the secretary at WVU (to avoid bias and improve validity), we will ask for your permission to tape the interview. Following the interview, the tape will be given to Dr. Lawrence who will send them to me for transcribing after which I will return them to Dr. Lawrence for disposal.

Thank you in advance for your participation in this study. Your cooperation is sincerely appreciated.

Sincerely,

Paul A. Lovett

Layle D. Lawrence

Graduate Student

Professor and Chair 
Appendix B

Interview Schedule 
Experiences of Selected West Virginia Agriculture Teachers Who Have Established Aquaculture Units in their Schools and Have Taught Aquaculture

Classes for Two Years or More

\section{Interview Schedule}

(Take up slack in tape w/pencil, insert new tape. Open door w/Stop/Eject. Install w/full reel to left. Close door)

Hello, Mr./Ms.

This is Alice Compton; I am the secretary in agricultural and environmental education at West Virginia University. A few days ago, you received a letter from Mr. Paul A. Lovett, agriculture teacher at Monroe County Technical Center, informing you of his thesis research study concerning your experiences in establishing and operating an aquaculture program in your school. If you have a few minutes, I would like to ask you the questions that Mr. Lovett wants answered. You may remember that this information is for Mr. Lovett's master's thesis, that your participation is voluntary, and that you don't have to answer every question if you prefer not to. We will keep the information you provide confidential, and hope the information obtained through this study will be beneficial to teachers who consider establishing aquaculture units in their school in the future. If it's all right with you, I would like to record our conservation. Do you mind? OK. Thanks. (Turn on machine-depress record and play) Only Mr. Lovett and Dr. Lawrence will have access to our taped conservation. Your name will not appear anywhere in the tape, which will maintain confidentiality. 
The first question:

Why did you decide to offer aquaculture in your school?

What did you remove from your curriculum, or how did you modify your curriculum, in order to offer aquaculture classes?

What has been the greatest payoff from offering aquaculture classes?

What have been the biggest drawbacks of offering aquaculture classes?

What do you think would be the optimum size of an aquaculture unit in a school system for educational purposes? (number and size(s) of tanks)

In your opinion what should be the focus for teaching aquaculture in the high school agriculture program (for example, to teach science concepts? to promote aquaculture production? to teach employment skills?)

To what extent is aquaculture as a Supervised Agriculture Experience Program being promoted? (outside of school)

With regard to the aquaculture program, what would you do differently if you had it to do all over?

That's all! Thank you very much for your cooperation. We sincerely appreciate it. Goodbye

(Hit Stop/eject. Remove tape. Check teacher's name off list.) 
Paul A. Lovett

Born: Fairfax, Virginia -1956

Parents: Paul A. and Earlyne Lovett

Education: Fairfax High School graduated 1973

West Virginia University, graduated 1978, Bachelor of Science Degree, in Agriculture Education

West Virginia University, graduated 1999, Master Degree, Agriculture

Education

Employment: Monroe County Technical Center, Lindside, West Virginia

1983 to the present, teach aquaculture, co-op, agriculture education IV

1978-1983 Taylor County Technical Center, Grafton, West Virginia

Taught- Buildings and Grounds Maintenance

Honors: West Virginia Honorary State FFA Degree- 1997

West Virginia Agri-Science Teacher of the Year- 1997

Family: Kristi Lovett-spouse

Todd and Scott Baker-stepsons

Emma Catherine Baker-granddaughter 